\title{
Platinum in sediments and mussels from the northwestern Mediterranean coast: temporal and spatial aspects
}

\author{
Abdou Melina ${ }^{1,{ }^{*}}$, Schäfer Jörg ${ }^{1}$, Hu Ruoyu ${ }^{1}$, Gil-Díaz Teba ${ }^{1}$, Garnier Cédric ${ }^{2}$, \\ Brach-Papa Christophe ${ }^{3}$, Chiffoleau Jean-Francois ${ }^{3}$, Charmasson Sabine ${ }^{4}$, Giner Franck ${ }^{4}$, \\ Dutruch Lionel ${ }^{1}$, Blanc Gerard ${ }^{1}$
}

${ }^{1}$ University of Bordeaux, UMR CNRS 5805 EPOC, 33615 Pessac Cedex, France

${ }^{2}$ Laboratoire PROTEE, Université du Sud Toulon-Var, BP 20132, 83957 La Garde, France

${ }^{3}$ IFREMER, LBCM, Centre Atlantique, Rue de l'lle d'Yeu, 44311 Nantes, France

${ }^{4}$ IRSN, PSE-ENV/SRTE/LRTA, CEA CADARACHE, 13115 Saint Paul Lez Durance, France

*Corresponding author : Melina Abdou, email address : $\underline{\text { melina.abdou@u-bordeaux.fr }}$

\begin{abstract}
:
Platinum (Pt) is considered a Technology Critical Element (TCE) and an emerging metallic contaminant with increasing release into the environment. Gaps in knowledge and understanding of environmental levels, fate and effects of Pt still exist, especially in the marine environment. This work presents $\mathrm{Pt}$ concentrations in the northwestern Mediterranean coast including: (i) temporal variability from sediment cores and farmed mussels in the Toulon Bay (historically affected by intense human activities) and (ii) spatial distribution from recent wild mussels collected along $\sim 300 \mathrm{~km}$ coastline with contrasting ecosystems (including natural reserves), quantified using voltammetry and inductively coupled plasmamass spectrometry. The historical (> 100 years) record of Pt in sediments from the Toulon Bay suggests the existence of non-negligible Pt sources older than those related to vehicle emission devices, such as petrol industry and coal-fired activities. A strong Pt increase in more recent sediments (from $\sim 12$ to 16 ng.g-1) and mussels (8-fold increase from $\sim 0.12$ to $0.80 \mathrm{ng} . \mathrm{g}-1$ ) covering the past 25 years reflect the overall evolution of Pt demand in Europe ( 20-fold increase for vehicle catalysts in 20 years). Spatial biomonitoring of $\mathrm{Pt}$ in mussels along the northwestern Mediterranean coast is assumed to reflect intersites differences of Pt exposure (0.09 to $0.66 \mathrm{ng} . \mathrm{g}-1)$ despite seasonal effect on tissue development. This study highlights the need for thorough and regular monitoring of Pt levels in sediments and biota from urbanized coastal areas in order to better assess the environmental impact of this TCE, including potential risks for marine organisms.
\end{abstract}

\section{Highlights}

- Platinum levels were monitored in contrasting sites of the NW Mediterranean coast - Historical sediments reflect non-vehicle related, old Pt anthropogenic sources - Past 25-years sediments and mussels show recent vehicle related $\mathrm{Pt}$ contamination Biomonitoring mussels reflect the degree of $\mathrm{Pt}$ contamination in coastal environment

Keywords : Platinum, sediments, mussels, biomonitoring, Mediterranean coast 


\section{Introduction}

Platinum is a Technology Critical Element (TCE) and an emerging metallic contaminant for which there is a growing need for accurate assessment of environmental distribution and impacts (Cobelo-García et al., 2015). This element is increasingly used in various applications due to its high chemical resistance and excellent catalytic properties. Anthropogenic activities account for more than $80 \%$ of Pt fluxes at the Earth surface (Sen and Peucker-Ehrenbrink, 2012). Today, the most extended application is the use of Pt in vehicle catalytic converters to control air pollution by cars, trucks, motorcycles and non-road mobile machinery, accounting for more than $70 \%$ of the European Pt demand (Johnson Matthey, 2017).

Increasing Pt emissions from automobile exhaust catalytic converters have led to an increase in Pt concentration in many environmental compartments including atmosphere, soils, sediments, interstitial waters, and seawater with anomalies occurring even in very remote, supposedly pristine areas such as the Antarctic snow (e.g. Almécija et al., 2015; Obata et al., 2006; Rauch et al., 2004, 2006; Schäfer et al., 1999; Schäfer and Puchelt, 1998; Soyol-Erdene et al., 2011). Increasing Pt concentrations are also recorded in aquatic organisms comprising plants, bivalves, and marine mammals which prove to bioaccumulate this element (Abdou et al., 2016; Almécija et al., 2016; Essumang, 2008; Neira et al., 2015). In spite of growing efforts to improve the understanding of biogeochemical Pt cycles, there is still a lack of relevant environmental data. This is particularly the case in marine environments, mainly due to analytical challenges when analyzing Pt at ultra-trace levels in complex environmental matrices (i.e. seawater, sediments and biota). In fact, only few field studies report on Pt levels, distribution and geochemical behavior in coastal ecosystems. Coastal areas are considered as vulnerable sites due to their anthropogenic socio-economic roles, hosting $\sim 70 \%$ of the urban populations and economic activities worldwide (Small and Nicholls, 2003). This pressure implies the risk of serious environmental consequences (McGranahan et al., 2007) such as trace metal contamination and 
59

60

possible transfer to the marine food web. Evidence of measurable anthropogenic Pt inputs into the coastal environment are especially based on the analysis of sediment cores (e.g. Rauch et al., 2004; Tuit et al., 2000). The few papers reporting on Pt in coastal seawater suggest that supposedly uncontaminated surface seawater shows dissolved Pt concentrations in the range of 0.05 - 0.1 ng.L -1 $^{-1}$ (e.g. Cobelo-García et al., 2014a; Goldberg et al., 1986). The even more limited number of field studies reporting on Pt concentrations in marine organisms prove Pt bioavailability and relatively high potential for Pt bioconcentration, especially in marine bivalves (Abdou et al., 2016; Neira et al., 2015). Accordingly, these organisms appear as suitable biomonitors to assess Pt levels in marine environments (Abdou et al., 2018).

The Mediterranean Sea is a semi-enclosed system with ever growing anthropogenic pressure along its northwestern coast (Durrieu de Madron et al., 2011; Martín et al., 2009) that comprises several highly populated cities with extensively urbanized and industrialized areas. The progressive urbanization of this coastal area and the possible changes of seawater chemistry due to additional anthropogenic inputs have already been reported in previous studies addressing environmental quality of the Mediterranean coast. Indeed, evidences exist on heavy metal pollution (e.g. Oursel et al., 2013; Tessier et al., 2011), metal-organic components (e.g. organotin; Pougnet et al., 2014) and nutrients (Ruggieri et al., 2011), especially at historically exposed sites and major harbors, such as the Toulon Bay or the Genoa Harbor. The United Nations Environment Program (UNEP) has implemented the Program for the Assessment and Control of Marine Pollution in the Mediterranean (MED POL) among other environmental initiatives. Among the sources of pollution monitored are important shipping industry, oil, gas and chemical industries that are widely developed in the NW Mediterranean coast (UNEP, 2017).

The present work aims at providing an assessment of Pt levels in: (i) historical samples (sediment cores and farmed mussels) from an industrial and strongly urbanized Mediterranean 
84 harbor (Toulon Bay, France), and (ii) wild mussels from selected, contrasting sites along

$85300 \mathrm{~km}$ of the northwestern Mediterranean coast, including industrial sites supposedly 86 influenced by Pt-releasing anthropogenic activities.

\section{Material and Methods}

The northwestern Mediterranean coast is characterized by high urbanization and numerous harbors, with areas that have faced centuries of intense anthropogenic pressure due to urban and industrial emissions, trade, war material spills, navigation, dredging and fishery among other activities. Progressive intense urbanization has led to a general anthropogenically-derived chronic pollution by multiple contaminants of various origins (e.g. trace metals, Oursel et al., 2013). Different sets of samples were collected at contrasting sites in France and Italy, covering a coastline of $\sim 300 \mathrm{~km}$ in the northwestern Mediterranean (Fig. 1).

\section{The Toulon Bay}

Long-term evolution of Pt in a harbor affected by strong multi-component pollution was studied in sediment cores and farmed mussels from the Toulon Bay (TB, Fig. 1). The Toulon Bay is divided into two parts by an artificial embankment, forming the Large Bay and the Small Bay

101 (LB and SB, respectively; Fig. 1) and receives urban inputs from Toulon city ( 600,000

102 inhabitants, Tessier et al., 2011). The Toulon Bay has been strongly polluted by anthropogenic wastes originating from both historic (bombardments and fleet scuttling during World War II: one hundred ships destroyed and sunk, mainly in the Small Bay) and ongoing activities (French

105 Navy, commercial traffic, urban raw sewage release, industry, tourism; Dang et al., 2015;

106 Tessier et al., 2011). Accordingly, high levels of inorganic and organic pollutants are 
107 accumulated in sediments from the Toulon Bay (e.g. Dang et al., 2015; Pougnet et al., 2014;

108 Tessier et al., 2011). Both sediment cores and mussels were sampled in the SB characterized

109 by a semi-closed shape with a surface of $\sim 9.8 \mathrm{~km}^{2}$ where the morphology and the artificial

110 barrier limit water circulation favoring accumulation of sediment and associated contaminants

111 (Fig. 1, Tessier et al., 2011).

112 The sediment cores were sampled by the laboratory PROTEE from November 2008 to June

1132009 in the context of a wider survey on sediment quality in the Toulon Bay (Tessier et al.,

114 2011). The two sediment cores analyzed in this study were collected at sampling site TB1

115 located in the eastern part of SB, close to a former Navy submarine base and in the main

116 navigation channel; and at site TB2 located in the western part of SB, close to a fish/mussel

117 farming area (Fig. 1). The sediment cores were processed as previously described in Tessier et

118 al. (2011). Briefly, $10 \mathrm{~cm}$ diameter and $1 \mathrm{~m}$ long (Interface Corer, Plexiglas ${ }^{\circledR}$ tube) sediment

119 cores were transported to the laboratory PROTEE directly after sampling and sliced $(2 \mathrm{~cm}$

120 resolution) under inert atmosphere $\left(\mathrm{N}_{2}\right)$ to preserve redox conditions. The sliced sediment

121 samples were pooled and homogenized (Teflon spoon), placed into pre-cleaned $1 \mathrm{~L}$ high-

122 density polyethylene (HDPE) bottles and deep frozen $\left(-18^{\circ} \mathrm{C}\right)$. All frozen samples were

123 subsequently freeze-dried (within one month) and sieved (2 mm).

124 Farmed mussels (35 - 65 mm, Mytilus galloprovincialis) were sampled annually since 1984 at 125 the sampling site TB2 (Fig. 1) by the RNO-ROCCH mussel watch program (IFREMER).

126 Freeze-dried soft tissues (pooled total soft bodies of more than 30 individuals) from the National

127 Mussel Watch sample bank (storage at room temperature and in the dark) were selected,

128 covering the period from 1984 to 2014 at 3-years intervals. 
131 Wild mussels (M. galloprovincialis) were sampled at contrasting sites along the northwestern

132 Mediterranean coastline: in Banyuls-sur-Mer, Sète, Saintes-Marie-de-la-Mer, Faraman, and

133 Toulon Bay (respectively BM, ST, SMM, FM, TB; Fig. 1) and in the South of the Corsica Island

134 (Bonifacio, BF, Fig. 1) by the IRSN (French Institute for Radioprotection and Nuclear Safety)

135 within a regular monitoring program (2016-2017). In addition, wild mussels from the Genoa

136 Harbor were collected (GH, Fig. 1) during a field campaign held in April 2016. After manual

137 collection, mussels $(\sim 7 \mathrm{~cm})$ were cleaned, opened, and soft tissue and shells were weighed

138 separately. This sampling scheme cover a great diversity of expected pollution levels

139 (industrialized and preserved sites). Accordingly the sampling sites Banyuls-sur-Mer, Sète,

140 Faraman, and Bonifacio are located in natural preserved area with no expected source of

141 pollution. The sampling site Saintes-Marie-de-la-Mer is in a leisure harbor and therefore

142 potentially more affected by pollution whereas the sites Toulon Bay and Genoa Harbor

143 represent two major harbors of the NW Mediterranean Coast. Several pollution source are

144 expected since they are characterized by petroleum, industrial fumes and urban runoff pollution

145 (Baumard et al., 1998). The Condition Indices (CI = Visceral Content, wet weight / Shell, wet

146 weight; Strady et al., 2011) were determined for all the samples. For samples collected along

147 the French coastline, each sampling corresponded to the collection of $\sim 240$ individuals that

148 were pooled. For samples collected in the Genoa Harbor, 10 organisms were processed

149 individually. Mussel tissues were then oven-dried at $80^{\circ} \mathrm{C}$ to constant weight and dried tissues

150 were kept at room temperature in the dark pending analysis.

151 Seasonal trace metal level variations have been observed in M. galloprovincialis related to

152 variable soft-body weight during reproduction periods (e.g. Charmasson et al., 1999, Erk et al.,

153 2018). Accordingly, in Spring, Summer, and early Fall, gonads contain developing and mature

154 gametes and represent up to $35 \%$ of the total body weight, while Autumn and early Winter 
155 correspond to the period of gametogenic quiescence and associated lower metabolic rate

156 (Widdows, 1978). In order to observe the seasonality of Pt concentrations, mussel samples from

157 Winter (December - February) were analyzed together with mussels from Spring and

158 Summer / Fall (July - October) from the same site, when both sets of samples were available.

159 For the sampling sites Banyuls-sur-Mer, Bonifacio, and Genoa Harbor, only mussel samples

160 from dates within the reproduction cycle were analyzed (July 2016, October 2016, and April

1612016 respectively).

162

163

164

165

166

167

168

169

170

171

172

173

174

175

176

177

178

2.2. Analytical methods

\section{Sediment}

Platinum concentrations in sediment core samples were determined by Adsorptive Cathodic Stripping Voltammetry (AdCSV) as described in Cobelo-García et al. (2014b). Measurements were carried out using a $\mu$ Autolab Type III potentiostat (Metrohm ${ }^{\circledR}$ Autolab B.V.) connected to a polarographic stand (Metrohm ${ }^{\circledR} 663$ V.A.) equipped with three electrodes: (i) a hanging mercury drop electrode (HMDE, the working electrode), (ii) a silver/silver-chloride (Ag/AgCl) reference electrode, and (iii) a glassy carbon auxiliary electrode. A polytetrafluoroethylene (PTFE) voltammetric cell served in all experiments and the potentiostat was controlled using the NOVA 2.1 software. According to the protocol for sediment treatment described by CobeloGarcía et al. (2011), about $50 \mathrm{mg}$ of sediment samples were ashed in porcelain crucibles at $800{ }^{\circ} \mathrm{C}$ during $3 \mathrm{~h}$ (removal of Organic Matter, OM). Ashed samples were transferred into $30 \mathrm{~mL}$ perfluoroalkoxy (PFA) vessels with screw caps (Savillex $\left.{ }^{\circledR}\right)$ and acid-digested at $195^{\circ} \mathrm{C}$ for $4 \mathrm{~h}$ using $5 \mathrm{~mL} \mathrm{HCl}$ and $3 \mathrm{~mL} \mathrm{HNO}_{3}\left(30 \% \mathrm{HCl}\right.$ and $65 \% \mathrm{HNO}_{3}$ Suprapur, Merck $\left.{ }^{\circledR}\right)$. After this step, vessel caps were removed and the acids evaporated at $195{ }^{\circ} \mathrm{C}$ until near dryness. The residue was re-dissolved using $1 \mathrm{~mL}$ of sulfuric acid $\left(\mathrm{H}_{2} \mathrm{SO}_{4}, 93-98 \%\right.$ Trace metal grade, 
179 Fisher Chemical ${ }^{\circledR}$ ) at $195^{\circ} \mathrm{C}$. Cooled contents were diluted using $0.1 \mathrm{M} \mathrm{HCl}$, centrifuged at $4000 \mathrm{rpm}$ for $10 \mathrm{~min}\left(20^{\circ} \mathrm{C}\right)$, and made up to $25 \mathrm{~mL}$ in pre-clean Teflon bottles (Nalgene $\left.{ }^{\circledR}\right)$.

Aliquots of acid-digested sample (dilution 1:1 with MilliQ water ${ }^{\circledR}$ ) were pipetted into the voltammetric cell together with $30 \mu \mathrm{L}$ of $3.3 \mathrm{mM}$ formaldehyde (37-41\% Analytical Reagent Grade, Fisher Chemical ${ }^{\circledR}$ ), $30 \mu \mathrm{L}$ of $0.45 \mathrm{mM}$ hydrazine sulfate (Analytical Reagent Grade,

184 Fisher Chemical ${ }^{\circledR}$ ), and $300 \mu \mathrm{L}$ of $\mathrm{H}_{2} \mathrm{SO}_{4}$. Platinum concentrations were determined by standard addition method (adding mono-elementary Pt standard solution $1000 \mu \mathrm{g} . \mathrm{mL}^{-1}$ PLASMACAL, SCP Science ${ }^{\circledR}$ ) using a deposition time of $90 \mathrm{~s}$ and experimental parameters as described elsewhere (Cobelo-García et al., 2014b).

Mussels

A previous inter-method comparison using two completely independent digestion and measurement techniques (Inductively Coupled Plasma-Mass Spectrometry: ICP-MS and AdCSV) has shown that Pt concentrations in natural biological samples (oysters) can be reliably measured by ICP-MS when sufficient sample mass (i.e. $\sim 0.25 \mathrm{~g}$ dry weight, $0.13 \mathrm{ng} \mathrm{Pt}$ ) is available (Abdou et al., 2018). Indeed, hafnium-oxides $\left(\mathrm{HfO}^{+}\right)$interferences that may prevent correct analysis of Pt in biological matrices (Godlewska-Żyłkiewicz, 2004; Pyrzynska, 2015) can be mathematically corrected using the ${ }^{193} \mathrm{Ir}$ (iridium) signal that is highly interfered by $\mathrm{HfO}^{+}$

196 (Abdou et al. 2018, Djingova et al., 2003). The ICP-MS method can therefore be an alternative

197 to AdCSV for detection of Pt in biological samples. Due to relatively low sample mass available

198 for farmed mussels from the Toulon Bay, these samples were analyzed by AdCSV applying the

199 same procedure as for sediment cores, using a deposition time of $180 \mathrm{~s}$. In contrast, sufficient 200 sample mass was available for the wild mussel samples from the Mediterranean coastline, 201 allowing for the time saving analysis using ICP-MS (ICP-MS, Thermo, X Series II). About $2021.5 \mathrm{~g}$ of sample was ashed at $800{ }^{\circ} \mathrm{C}$ in porcelain crucibles. After cooling, ashed residues were transferred into acid-cleaned polypropylene (PP) tubes (DigiTUBEs, SCP SCIENCE®), and 
204 digested at $110^{\circ} \mathrm{C}$ for $3 \mathrm{~h}$ with $2 \mathrm{~mL} \mathrm{HCl}$ and $1 \mathrm{~mL} \mathrm{HNO}_{3}\left(30 \% \mathrm{HCl}\right.$ and $65 \% \mathrm{HNO}_{3}$ 205 Suprapur, Merck ${ }^{\circledR}$ ) as described in Abdou et al. (2018) for environmental samples. Cooled 206 contents were then diluted in $10 \mathrm{~mL}$ MilliQ water ${ }^{\circledR}$, centrifuged at $4000 \mathrm{rpm}$ for $10 \mathrm{~min}$ $207\left(20^{\circ} \mathrm{C}\right)$. Analyses were performed applying the standard addition method (using mono208 elementary Pt standard solution $1000 \mu \mathrm{g} \cdot \mathrm{mL}^{-1}$ PLASMACAL, SCP Science $\left.{ }^{\circledR}\right)$.

\section{Quality control}

210 Quality control was performed using the only Certified Reference Materials available for Pt 211 being the BCR ${ }^{\circledR}-723$ road dust (IRMM) and the Jsd-2 sedimentary rocks (indicative value from 212 GSJ). Platinum quantification by AdCSV provided satisfactory recovery of $89 \%$ for BCR ${ }^{\circledR}$ 213723 and $98 \%$ for Jsd-2 $(n=3)$ as well as ICP-MS analyses giving recovery values of $87 \%$ and $214101 \%$ respectively. Uncertainty of the analysis, expressed as Relative Standard Deviation 215 (RSD\%), was below 10\% using both methods. In addition, in the absence of any biological

216 CRM for Pt, a previous study inter-compared ICP-MS and AdCSV as different, independent 217 analytical method. Results for similar sample masses as applied in the present study allowed 218 for reproducible and similar $(<3 \%$ difference in average) results for both methods indicating 219 good accuracy. The detection limit for particulate (sediment and biota) Pt measured by AdCSV 220 (calculated as $3 \mathrm{x}$ blank standard deviation, $\mathrm{n}=5$ ) was estimated to $0.03 \mathrm{ng} \cdot \mathrm{g}^{-1}$ for typical mass 221 of $50 \mathrm{mg}$. The detection limit for Pt measured in biological samples by ICP-MS ( $\mathrm{n}=10$ blanks) 222 was estimated to $0.003 \mathrm{ng} \cdot \mathrm{g}^{-1}$ for typical biological sample masses of $\sim 1.5 \mathrm{~g}$. 


\section{Results}

3.1. Historical record of $\mathrm{Pt}$ concentrations in sediments and mussels from the

225

226

\section{Toulon Bay}

Platinum concentrations in the two sediment cores TB1 and TB2 ranged from $6 \mathrm{ng}^{-\mathrm{g}^{-1}}$ to 15 ng. $\mathrm{g}^{-1}$ (Fig. 2A). Samples in the TB1 core showed relatively constant Pt levels of $\sim 10$ ng.g-1, with only a small variation at $5 \mathrm{~cm}$ depth showing Pt concentration of $\sim 7 \mathrm{ng}^{-g^{-1}}$. In contrast, the core TB2 showed a general trend of Pt concentrations decreasing with depth, i.e. the highest concentrations occurred in the top of the core and the lowest values in the bottom (Fig. 2A). Overall, the Pt concentrations tended to be lower in the core TB1 than in TB2. When comparing sediment samples from different depths or different cores, one has to exclude that the observed variations are due to grain size effects because particle size fractionation may lead to increasing trace metal concentrations with decreasing grain size (Loring and Rantala, 1992). Accordingly, grain size effects on natural, lithogenic trace metal variability must be corrected by normalization over a grain size dependent lithogenic element before assessing anthropogenic inputs (Loring and Rantala, 1992). Aluminum (Al) has been chosen as the normalization element for the Toulon Bay and many other systems (e.g. Ho et al., 2012; Pougnet et al., 2014; Tessier et al., 2011), as Al contents are influenced by natural sedimentation and the effects of enhanced erosion, but not by pollution ( $\mathrm{Li}$ and Schoonmaker, 2003; Luoma and Rainbow, 2008). In fact, correlation $\left(\mathrm{R}^{2}=0.94\right)$ between potassium $(K)$ and $\mathrm{Al}$ concentrations in surface and deep sediment showed the close relationship between Al and clay minerals, supporting the pertinence of Al-normalization (Tessier et al., 2011). In both cores, Al-normalization did not modify the profiles, suggesting that grain size effects on spatial (horizontal and vertical) Pt distribution are negligible (Fig. 2B). These results suggest that in the sediment core TB2 (i) nearly all layers are enriched in Pt compared to the core TB1 and (ii) there is a clear increasing trend in Pt enrichment from the bottom to the top of the core (3-fold; Fig. 2). 
249 Platinum concentrations in farmed mussels from the Toulon Bay ranged from 0.10 to $250 \quad 0.79$ ng.g ${ }^{-1}$, in the 1984 to 2014 period (Fig. 3). Platinum concentrations were relatively low 251 and constant $\left(\sim 0.15 \mathrm{ng} \cdot \mathrm{g}^{-1}\right)$ from 1984 to 1990 , followed by a clearly increasing trend over time

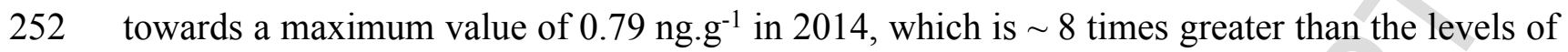
253 the 1980's. In the same period, the European Pt gross demand for car catalytic converters 254 evolved from 1-2 tons. $\mathrm{y}^{-1}$ in the late 1980 s to $\sim 40$ tons. $\mathrm{y}^{-1}$ from 2010 to 2014 (Fig. 3).

Platinum concentrations in wild mussels from contrasting sites, expressed in $n g . \mathrm{g}^{-1} \mathrm{dw}$ ranged from $\sim 0.09$ to 0.66 ng.g-1 (Fig. 4). Winter mussels were compared to Spring and Summer / Fall mussels, whenever possible as described in section 2.1 .

Winter mussel Pt concentrations varied from $\sim 0.33$ to 0.55 ng. $\mathrm{g}^{-1}$ (black bars; Fig. 4). For those mussels, Pt concentrations at the different sites tended to increase from the western to the eastern sites along the coast (Sète to Toulon Bay). Winter mussels from Sète sampling site showed the lowest Pt levels, while highest concentrations occurred in mussels from Faraman 264 site and from the Toulon Bay.

265 Summer / Fall mussel Pt concentrations ranged from 0.09 to 0.66 ng.g ${ }^{-1}$ (white bars; Fig. 4), 266 with mussels from Sète showing the lowest concentrations at a given sampling period, while 267 highest concentrations occurred in mussels from the Toulon Bay. Platinum concentrations were 268 also determined in wild mussels collected in the Genoa Harbor in April 2016. Ten individuals 269 were analyzed separately, providing an average Pt concentration of $0.48 \pm 0.14$ ng.g-1 (Genoa 270 Harbour, Fig. 4). Condition Indices varied from 17 to 47 between sites and sampling periods. 271 Spring and Summer / Fall individuals showed CI ranging from 21 to 47 with a mean value of 27231 , while it varied from 17 to 23 with a mean value of 20 in Winter organisms. 


\section{Discussion}

4.1. Historical records of Pt concentrations in the Toulon Bay

Two complementary approaches to study the temporal evolution of Pt in the Toulon Bay rely on the analysis of environmental archives: sediment cores and mussel samples from a historical sample bank, implying different time scales and resolution.

\section{Historical record in sediments}

Average sedimentation rate in the Toulon Bay sediments was estimated from the vertical distribution of ${ }^{210} \mathrm{~Pb}$ activity in the sediment cores in previous work (Tessier et al., 2011), suggesting an average sedimentation velocity of $0.21 \pm 0.05 \mathrm{~cm} \cdot \mathrm{y}^{-1}$. Accordingly, the studied sediment cores cover the period $\sim 1890-2008$ and the top $10 \mathrm{~cm}$ layer would reflect $\sim 50$ years of history (Tessier et al., 2011). As Al-normalization performed to correct for variations in sediment nature and grain size (Sageman and Lyons, 2003) did not modify the Pt profiles in the Toulon Bay sediments (Fig. 2B), the observed variations are attributed to anthropogenic inputs, rather than lithogenic processes, as described elsewhere (e.g. Almécija et al., 2016).

The assessment of the degree of contamination in a given environmental sample requires the establishment of references representing "uncontaminated" conditions in comparable sample types. Classically, authors have compared their results with average values of the Upper Continental Crust (UCC, e.g. Abdou et al., 2016; Cobelo-García et al., 2011; Rauch et al., 2004). This first approach may suggest that the Pt concentrations in the Toulon Bay sediments are clearly higher (up to 30 fold) than the UCC average (0.5 ng. $\mathrm{g}^{-1}$, Rudnick and Gao, 2003). More representative reference samples may be locally identified either in (i) remote areas, presumably not affected by the contaminant (spatial approach) or in (ii) samples representing conditions during periods before the contaminant release (temporal approach). Given the high spatial variability in (i) Pt global contaminant dispersion, measurable even in remote sites (e.g. 
polar ice, Soyol-Erdene et al., 2011) and (ii) heterogeneous sediment nature at a large spatial scale, we have considered to apply the temporal approach to reliably determine the contamination degree of Pt in the Toulon Bay.

In fact, Pt concentrations in the bottom layers of the sediment cores, i.e. $\sim 10$ ng. $\mathrm{g}^{-1}$ in core TB1 and $\sim 6 \mathrm{ng}^{-\mathrm{g}^{-1}}$ in core TB2, supposedly dating from the early $20^{\text {th }}$ century, could serve as the local reference level for relatively uncontaminated sediment. These values may appear high, compared to background values reported for ancient sediments in the Tagus Estuary (0.2 0.3 ng.g-1 ${ }^{-1}$ Cobelo-García et al., 2011) or for the UCC Pt content. They are, however, similar in magnitude as Pt records from marine pristine sediment cores $\left(\sim 1\right.$ up to 5 ng.g - $^{-1}$ in Atlantic abyssal pelagic sediment; Colodner et al., 1992) and other pelagic sediments from a variety of locations in the Pacific ocean (0.4 to 22 ng.g-1 ${ }^{-1}$ Koide et al., 1991), both sampled before the recent emergence of $\mathrm{Pt}$ as a global contaminant. Furthermore, pre-anthropogenic coastal sediments from the Massachusetts Bay showed similar Pt levels than bottom layers from the Toulon Bay ( 5 ng.g ${ }^{-1}$, Tuit et al., 2000). These observations together with high Pt levels in South Pacific pelagic sediment ( 30 ng. $\mathrm{g}^{-1}$, Lee et al., 2003) and in marine manganese nodules (up to 900 ng.g-1 ${ }^{-1}$ Koide et al., 1991) tend to suggest that relatively high Pt concentrations in coastal sediments may, at least partly, be attributed to the presence of marine particles and not necessarily derive from terrigenous and/or anthropogenic sources. Accordingly, the Toulon Bay bottom sediments may be considered as the local, pre-industrial reference (especially core TB2). In fact, the Toulon Bay receives water from the open Mediterranean Sea via the Ligurian Current flowing from east to west including deep water areas (Duffa et al., 2011), transporting particles of marine origin into the bay. These findings highlight the need for better knowledge of marine particle baseline Pt concentrations in the Mediterranean Sea and worldwide, as a prerequisite to accurately evaluate anthropogenic contamination in coastal particles and sediments by distinguishing geochemical background from anthropogenic signals. 
The Pt/Al values suggest increasing concentrations from the bottom to the top in the core TB2 ( $\sim 3$-fold increase from the bottom to the top layers; Fig. 2B). However, the relatively small recent increase in $\mathrm{Pt} / \mathrm{Al}$ values $(\sim 20 \%$ in the period $\sim 1984-2008)$ combined with the relatively high values in the bottom of the core TB1 may be due to its position in the eastern part of the $\mathrm{SB}$, more exposed to the marine incoming water than the site TB2 (counterclockwise circulation in the Toulon Bay; Duffa et al., 2011). In addition, the site TB1 is located close to a main navigation channel, thus, one cannot fully exclude post-depositional Pt redistribution of the sediment. Post-depositional Pt redistribution processes might include both physical mixing (e.g. navigation, dredging...) and chemical redistribution related to diagenesis processes (Almécija et al., 2015; Tuit et al., 2000). Chemically-driven Pt mobility was already observed in other coastal sediments showing maximum Pt enrichment at the base of the surface mixed layer after scavenging at the oxic/anoxic boundary (Cobelo-García et al., 2011). Furthermore, a sediment core from the Boston Harbor also showed chemical mobility of Pt, implying Pt remobilization in sediments at short time scales (Tuit et al., 2000). According to Colodner et al. (1992), a fraction of Pt in marine sediments is labile, suggesting that Pt may be scavenged from seawater into both Fe-Mn oxyhydroxide minerals and organic-rich sediments, so that these phases might dominate the Pt distribution in sediments. Previous work has compared trace metal $(\mathrm{Cu}, \mathrm{Hg}$, $\mathrm{Pb}$, and $\mathrm{Zn}$ ) distributions in the same cores from the Toulon Bay showing some evidence of partial mixing in the core TB1 (Dang et al., 2015; Tessier et al., 2011).

In contrast, the position of the core TB2 in a shallow zone with low water regeneration (Tessier et al., 2011) and less impacted by currents, ship traffic and/or dredging, suggests that no major sediment reworking occurred. In this core, the continuous increase of Pt/Al over the past century before the mid-1980s cannot be explained by the relatively new technology of car catalytic converters, implying additional, yet less reported anthropogenic Pt sources to the marine environment. In fact, Pt concentrations in surface sediments from the Boston Harbor dating 
from 1978 (i.e. integrating Pt emissions before the introduction of car catalysts) showed a 17-

348 fold enrichment of Pt concentrations relative to background values (i.e. up to $12.5 \mathrm{ng} \cdot \mathrm{g}^{-1}$, Tuit

349 et al., 2000). This observation suggests that, despite the higher Pt release rates of the early

350 catalytic converters and considering the relatively low number of catalyst-equipped cars at that

351 time, other, probably industrial sources may have affected the Pt levels in harbor sediments

352 (Tuit et al., 2000). Older Pt emissions might be related to the use of $\mathrm{Pt}$ in several industrial

353 applications, since Pt played an important role in various catalytic processes (e.g. catalytic

354 cracking of crude petroleum) applied for the production of the very high octane fuels required

355 for aircraft and automobile engines during World War II (Peavy, 1958). After the war, Pt

356 catalyst reforming processes, introduced to the refining industry in 1949, produced huge

357 amounts of lower octane fuels for automobile engines, and industrial / home heating fuels.

358 Accordingly, the years 1950 to 1960 were considered as the industry's "platinum period"

359 (Peavy, 1958). In addition, emissions from intense coal industry during the first half of the $20^{\text {th }}$

360 century, may have contributed to elevated Pt concentrations, since high Pt concentrations were

361 reported for coal samples ( 5 ng.g ${ }^{-1}$, Finkelman and Aruscavage, 1981 ; up to 70 ng.g-1 , Dai et

362 al., 2003). As a result of the scuttling of the French Navy fleet during WWII (November 1942,

363 Tessier et al., 2011), huge amounts of industrial coal are still present in the surface sediments

364 inside the Toulon Bay with the area of the core TB2 being the coal loading dock (Dang et al.,

365 2018). Although the Pt concentrations in this coal are unknown, given the range of values

366 reported in the literature, industrial coal and/or fly ashes could partly explain the $\mathrm{Pt}$

367 accumulation in the core TB2, with a stronger increasing trend before $\sim 1960$, and a period of

368 weaker increase during $\sim 1960-1990$.

369 Recent increase of Pt concentrations ( $\sim 50 \%$ increase in $\sim 24$ years in core TB2; Fig. 2$)$ is

370 consistent with observations in other coastal environments, such as the Tagus Estuary. In this

371 system, Pt values at the top of the sediment core (up to 9.5 ng.g ${ }^{-1}$, Cobelo-García et al., 2011) 
representing $\sim 30-40$ times the local background are observed. Platinum concentrations in saltmarsh sediments impacted by high traffic in the same estuary showed a surface peak value exceeding 40 ng.g ${ }^{-1}$ (Almécija et al., 2015). This recent contamination has been clearly attributed to increasing Pt demand, use and emission related to the introduction of car exhaust catalytic converters since the early 1990's (Rauch and Morrison, 2008). Considering Pt concentration originating from catalysts of $\sim 4$ ng. $\mathrm{g}^{-1}$ for the topmost samples in sediment core TB2, Pt deposition rates are estimated to $\sim 15 \mathrm{~g}^{\text {Pt. }} \mathrm{y}^{-1}$ based on an annual sedimentation rate of $\sim 0.2 \mathrm{~cm} \cdot \mathrm{y}^{-1}$, a density of wet sediment of $0.64 \mathrm{~g}^{\mathrm{cm}} \mathrm{cm}^{-3}$ and a porosity of 0.7 , as well as a SB surface of $9.8 \mathrm{~km}^{2}$ (Tessier et al., 2011). A rough estimation of Toulon Bay catalyst emission of $\sim 10$ to $20 \mathrm{~g} \mathrm{Pt.y}^{-1}$ is obtained assuming $\sim 200,000$ vehicles equipped with catalysts with an average yearly mileage of $1,000 \mathrm{~km} \cdot \mathrm{vehicle}^{-1}$ and an average emission rate ranging between 50 and 100 ng Pt.km-1 (based on values from Rauch and Peucker-Ehrenbrink, 2015). As observed on a global scale in Rauch et al. (2005), the difference between emission and deposition rates may originate from several factors including over-/underestimated emission rates which is influenced by the age and the type of vehicle (e.g. Moldovan e al., 2002) or the occurrence of recent additional sources (e.g. wastewaters and Pt from anticancer-drugs, Vyas et al., 2014). Literature reports that Pt emissions from cars are mainly deposited at a distance of less than 20 $\mathrm{m}$ from the edge of the road (e.g. Fritsche and Meisel, 2004; Schäfer and Puchelt, 1998). Overestimation of Pt inputs may also originate from the transfer of Pt emissions to seawater that is surely influenced by several factors including prevailing wind direction (Schäfer and Puchelt, 1998) and road runoff. Exportation of fine-grained urban particles towards the outer bay or the open sea by currents and/or potential partial Pt dissolution from urban particles in contact with seawater may also occur (Cobelo-García et al., 2014a). In addition, dissolved Pt will probably be diluted and exported rather than accumulated in sediments. Despite potential errors in the estimations, calculated Pt emission rates from car catalysts in the SB are generally in good 
agreement with recent $\mathrm{Pt}$ deposition rates in sediment core TB2 and might therefore explain a large fraction of total $\mathrm{Pt}$ deposition in the area.

\section{Historical record in mussels}

The temporal evolution of Pt concentrations in mussels farmed close to the site of core TB2 (Fig. 1) reflected a $\sim 8$-fold increase over the 1984 to 2014 period, especially since the mid1990s (Fig. 3). Together with the $\sim 20$-fold increase in European Pt demand for car catalysts over the same period, this observation suggests that vehicle-emitted Pt has been introduced into the coastal ecosystem of the Toulon Bay with an effective transfer to living marine organisms. These first results for Pt in Mediterranean bivalves are in line with increasing Pt/Al values in the TB2 core from the same site and with previous work on wild oysters and mussels from the French and the Spanish (Galician) Atlantic coast (oysters, Abdou et al., 2016; mussels, Neira et al., 2015). Given the fact, that biomonitoring organisms are sampled on a regular basis, sediment-specific uncertainties due to physical or chemical disturbance of the historical record are excluded and, therefore, the use of sentinel organisms from sample banks may provide reliable information on trends in ambient contaminant pressure over time. In fact, the recent $\mathrm{Pt}$ increase in mussels goes along with a decrease in $\mathrm{Pb}$ as observed in the same mussel samples from the Toulon Bay (Dang et al., 2015) and in Galician Mussels (Neira et al., 2015). These opposite trends may be explained by the successive ban of leaded gasoline (leading to decreasing $\mathrm{Pb}$ emissions) in parallel to the growing deployment of catalyst-equipped vehicles, since leaded gasoline damages the catalysts and thus is not compatible with this modern technology (Schäfer and Puchelt, 1998). The apparent baseline Pt concentration (0.1 ng g g Fig. 3) in Toulon Bay mussels could reflect either natural Pt background although one cannot exclude that these concentrations partly result from other historic Pt contamination as recorded in the sediment. 
Spatial distribution of $\mathrm{Pt}$ concentrations in mussels from contrasting sites along the Mediterranean coast seemed to roughly follow an increasing gradient from western to eastern sites, reflecting inter-site differences in terms of urbanization and supposed Pt inputs. Generally, in order to avoid trace metal variations related to seasonality, including reproduction, leading to "biological dilution" of gonads (Regoli and Orlando, 1994), Winter organisms are used for comparison. In those mussels, the lowest Pt concentrations occurred at the sampling site Sète. Low Pt concentrations also occurred in mussels available from sites Banyuls-sur-Mer (Natural Reserve of Cerbère-Banyuls) and Bonifacio (Summer / Fall mussels). All those three sites are located in supposedly less exposed areas, i.e. far from major urban areas. Slightly higher Pt concentrations $\left(\sim 0.4\right.$ ng. $\left.\mathrm{g}^{-1}\right)$ measured in Winter mussels from sampling site SaintesMaries-de-la-Mer cannot be explained by intense urban pressure, yet, mussel sampling was performed inside the leisure harbor. Even though the sampling site Faraman is located in a nonurbanized area (Natural Regional Park of Camargue), relatively high Pt concentrations $436\left(\sim 0.5\right.$ ng. $\left.\mathrm{g}^{-1}\right)$ in wild Winter mussels suggest contamination of this site, possibly by seawater 437 draining pollution from La-Fos-sur-Mer city. In fact, in the late 1980's, the Gulf of Fos was considered as one of the most polluted neritic areas in Europe with important metal pollution

$439 \mathrm{(Cu}, \mathrm{Pb}, \mathrm{Cd}, \mathrm{Zn}$; Benon et al., 1978). This area hosts important oil industries that might be a 440 source of Pt to the marine environment as previously discussed (section 4.1.). Other studies 441 report high trace metal contamination in native and caged mussels $M$. galloprovincialis from 442 areas close to major urban and industrial centers such as La-Fos-sur-Mer (Andral et al., 2004), 443 with a battery of biomarkers indicating disturbed health in mussels (Zorita et al., 2007) from 444 the most impacted zones including the La-Fos-sur-Mer Harbor. In addition the sampling site 445 Faraman is directly under the influence of the Rhône outflow (Charmasson et al., 1999) which 446 may drain all the pollution originating from the urbanized watershed. Similar Pt concentrations 
occurred in mussels from sampling site TB2 in the Toulon Bay (Seyne sur Mer), showing the highest Pt level $\left(0.55 \mathrm{ng} . \mathrm{g}^{-1}\right)$ of the studied sites. This value is somewhat lower than the 2014 value $\left(\sim 0.8\right.$ ng. $\left.\mathrm{g}^{-1}\right)$ in farmed mussels from the same area in the Toulon Bay. Platinum concentration range in mussels from the Genoa Harbor, marked by industrial / urban water pollution (Ruggieri et al., 2011), is similar to levels observed in the Toulon Bay (Fig. 4). These observations suggest that Pt accumulation in mussels from the different sites may reflect the supposed exposure from anthropogenic pressure, similarly to other trace metals, showing strong gradients between mussels from less populated areas or regions with no major river inputs (e.g. Sète) and those from heavily populated and industrialized port areas (Fowler and Oregioni, 1976).

Few field studies report on Pt levels in biota from coastal marine environments. Recent samples of wild mussels M. galloprovincialis from an urban beach in Vigo (Spain) revealed $\mathrm{Pt}$ concentrations of $\sim 0.45 \mathrm{ng} \cdot \mathrm{g}^{-1}$ (2011 value, Neira et al., 2015), while wild oysters (Crassostrea gigas) from the moderately contaminated Gironde Estuary mouth contained $\sim 0.33$ ng.g ${ }^{-1}(2013$ value, Abdou et al., 2016). Accordingly, Pt levels in mussels from the Mediterranean sites are similar in magnitude to those in wild bivalves from the Atlantic coast, but with clearly higher values in confined harbor sites with relatively high urban/industrial pressure. Bioconcentration factors (BCF), comparing Pt accumulation in tissues to ambient seawater concentrations were determined as $\mathrm{BCF}=\mathrm{Pt}_{\mathrm{B}} / \mathrm{Pt}_{\mathrm{D}}$, where $\mathrm{Pt}_{\mathrm{B}}$ is the $\mathrm{Pt}$ concentration in the organism $\left(n g . \mathrm{g}^{-1}, \mathrm{dw}\right)$ and $\mathrm{Pt}_{\mathrm{D}}$ the dissolved $\mathrm{Pt}$ concentration in seawater (ng. $\mathrm{L}^{-1}$, Arnot and Gobas, 2006) for the Genoa Harbor mussels (no $\mathrm{Pt}_{\mathrm{D}}$ data available for the other sites). Average $\mathrm{BCF}$ in the Genoa Harbor mussels was $\sim 4 \times 10^{3}$, i.e. similar to values reported for wild mussels $M$. galloprovincialis from an urban beach $\left(\sim 5 \times 10^{3}\right.$; Neira et al., 2015) and for wild oysters from the Gironde Estuary $\left(\sim 3 \times 10^{3}\right.$, Abdou et al., 2016). These values show that marine bivalve bioconcentrate Pt ambient signal reflecting: (i) the presence of natural bioavailable Pt species 
472

473

474

475

476

477

and (ii) their suitable use for Pt monitoring in coastal systems. Although it is assumed that dissolved metals are potentially more bioavailable than their particulate forms (e.g. Lekhi et al., 2008), filter-feeders such as mussels are able to absorb metals, and more particularly PGEs, in dissolved and particulate forms (Zimmermann and Sures, 2018). Given that Pt emissions from car exhaust systems mainly occur as very small particles (from micrometers down to nanometric size; Folens et al., 2018; Rauch et al., 2001), more work is necessary to characterize the behavior of such particles in the marine environment and understand their role in Pt transfer to living organisms.

Physiological status including growth and reproductive state may impact metal concentrations in bivalves, due to 'dilution' effects by rapid tissue growth or weight increase during gonad development (Casas et al., 2008; Couture et al., 2010). Therefore, contaminant concentrations in tissues reflect ambient concentrations, but also food availability or seasonal reproduction cycles (Andral et al., 2004; Charmasson et al., 1999; Dang et al., 2015). Inter-site comparison may require adjustment of raw concentration data from different sites with reference to a standard Condition Index to limit the risk of miss-interpretation, as shown from a mussel caging study, where site-dependent growth differences occurred at relatively short timescales (Andral et al., 2004). Comparison of Pt concentrations in the soft bodies of mussels sampled in Winter and in Spring and Summer/Fall from four of the seven studied sites clearly suggests that Pt concentrations undergo seasonal fluctuations (Fig. 4). The Condition Indices in the different mussel samples ranged from 17 to 47 with higher CI for Spring and Summer/Fall samples than for Winter samples, when comparison was available (Fig. 4). This result is expected supposing higher soft tissue mass during the reproduction season than during Winter. Indeed, during gametogenesis, the penetration of gonadic tissues into the digestive gland may biologically dilute metal concentrations in mussel total soft tissues (Regoli and Orlando, 1994). At three sites, the Winter concentrations are greater than the respective Summer values, as expected, 
497

498

499

500

501

502

503

504

505

506

507

508

509

510

511

512

513

514

515

516

517

whereas at the Toulon Bay site, Pt concentrations were higher in Summer, despite higher CI (Fig. 4). The latter observation might reflect environmental Pt exposure related with either sitespecific changes in bio-transfer or temporarily higher local Pt inputs (e.g. tourism related). However, these hypotheses cannot be validated with the available dataset. The observed seasonal fluctuations do not change the order of supposed Pt exposure between the studied sites (Sète to Toulon Bay; Fig. 1), suggesting that the uncertainties discussed above do not invalidate the spatial biomonitoring approach, yet warranting an optimized sampling strategy to limit potential biases.

\section{Conclusions}

Historical records of both sediment cores and mussels collected in a severely polluted site, the Toulon Bay, suggest the existence of former (non-vehicle related) sources of Pt in the system. They also revealed the impact of recent contamination related to increasing Pt emissions through car catalytic converters that may be of major importance in this area under high anthropogenic pressure. Biomonitoring in mussels from contrasting areas along the northwestern Mediterranean coastline suggests a relation between the degree of exposure and the Pt concentrations in mussel tissues. Mussels could therefore be considered as a potential good bioindicator of Pt levels in marine environments. Considering the relatively high $\mathrm{Pt}$ concentrations in some sampling sites, systematic (bio-)monitoring programs should therefore be run in such coastal environments marked by historical and current Pt contamination. Continuous metal inputs to the coastal zone may lead to increasing pollution in these already highly contaminated areas with the risk of Pt export to the marine environment. Further investigations are therefore of major importance to accurately determine biogeochemical $\mathrm{Pt}$ distribution, reactivity and fate in marine waters. 


\section{Acknowledgements}

522 This work has benefited from the support by the FEDER Aquitaine-1999-Z0061, the Agence 523 de l'Eau Adour-Garonne 32022123 and 31033111, the COST Action TD1407, and the EU FP7 524 Ocean 2013.2 Project SCHeMA (Project-Grant Agreement 614002), which is gratefully 525 acknowledged. Authors also gratefully acknowledge the help of the UNIGE-It Team, for 526 sampling and assistance in the Genoa Harbor, and of A. Lerat and C. Pereto for dissection. The 527 authors thank the French Navy for logistical support (access to restricted areas, vessel, scuba 528 divers) and D. François, G. Tua, G. Durrieu and B. Oursel for their participation in sampling 529 campaigns and sample preparation within the CARTOCHIM Project. The CARTOCHIM 530 project has been performed by a multi-agency consortium (IFREMER, IRSN, University 531 laboratories PROTEE and UMR EPOC), financially supported by the "Region PACA", 532 “Toulon-Provence- Méditerranée" and the "Agence de l'Eau Rhône-Méditerranée et Corse" 533 and is a contribution to MerMex-WP3-C3A and the international IMBER projects. 


\section{References}

535

536

537

538

539 mussel caging. Mar. Pollut. Bull. 49 , 704-712. 
Arnot, J.A., Gobas, F.A.P.C., 2006. A review of bioconcentration factor (BCF) and

557

558

559

560

561

562

563

564

565

566

567

568

569

570

571

572

573

574

575

576

577

578

bioaccumulation factor (BAF) assessments for organic chemicals in aquatic organisms.

Environ. Rev. 14, 257-297. https://doi.org/10.1139/A06-005

Baumard, P., Budzinski, H., Garrigues, P., 1998. Polycyclic aromatic hydrocarbons in sediments and mussels of the western Mediterranean sea. Environ. Toxicol. Chem. 17, 765776. https://doi.org/10.1002/etc.5620170501

Benon, P., Blanc, F., Bourgade, B., David, P., Kantin, R., Leveau, M., Romano, J.-C., Sautriot, D., 1978. Distribution of some heavy metals in the Gulf of Fos. Mar. Pollut. Bull. 9, 71-75. https://doi.org/10.1016/0025-326X(78)90452-6

Casas, S., Gonzalez, J.-L., Andral, B., Cossa, D., 2008. Relation between metal concentration in water and metal content of marine mussels (Mytilus galloprovincialis): Impact of physiology. Environ. Toxicol. Chem. 27, 1543-1552. https://doi.org/10.1897/07-418.1

Charmasson, S., Barker, E., Calmet, D., Pruchon, A.S., Thébault, H., 1999. Long-term variations of man-made radionuclide concentrations in a bio-indicator Mytilus galloprovincialis from the French Mediterranean coast. Sci. Total Environ. 237-238, 93-103.

Cobelo-García, A., Filella, M., Croot, P., Frazzoli, C., Du Laing, G., Ospina-Alvarez, N., Rauch, S., Salaun, P., Schäfer, J., Zimmermann, S., 2015. COST action TD1407: network on technology-critical elements (NOTICE)--from environmental processes to human health threats. Environ. Sci. Pollut. Res. Int. 22, 15188-15194. https://doi.org/10.1007/s11356-0155221-0

Cobelo-García, A., López-Sánchez, D.E., Schäfer, J., Petit, J.C.J., Blanc, G., Turner, A., 2014a. Behavior and fluxes of Pt in the macrotidal Gironde Estuary (SW France). Mar. Chem. 167, 93-101. https://doi.org/10.1016/j.marchem.2014.07.006 
579 Cobelo-García, A., Neira, P., Mil-Homens, M., Caetano, M., 2011. Evaluation of the 580 contamination of platinum in estuarine and coastal sediments (Tagus Estuary and Prodelta, 581 Portugal). Mar. Pollut. Bull. 62, 646-650. https://doi.org/10.1016/j.marpolbul.2010.12.018

582 Cobelo-García, A., Santos-Echeandía, J., López-Sánchez, D.E., Almécija, C., Omanović, D., 583 2014b. Improving the voltammetric quantification of ill-defined peaks using second derivative 584 signal transformation: Example of the determination of platinum in water and sediments. Anal. 585 Chem. 86, 2308-2313. https://doi.org/10.1021/ac403558y

586 Colodner, D.C., Boyle, E.A., Edmond, J.M., Thomson, J., 1992. Post-depositional mobility of 587 platinum, iridium and rhenium in marine sediments. Nature 358, 402. 588 https://doi.org/10.1038/358402a0

589 Couture, R.-M., Chiffoleau, J.-F., Auger, D., Claisse, D., Gobeil, C., Cossa, D., 2010. Seasonal 590 and Decadal Variations in Lead Sources to Eastern North Atlantic Mussels. Environ. Sci.

591 Technol. 44, 1211-1216. https://doi.org/10.1021/es902352z

592 Dai, S., Ren, D., Zhang, J., Hou, X., 2003. Concentrations and origins of platinum group 593 elements in Late Paleozoic coals of China. Int. J. Coal Geol. 55, 59-70. 594 https://doi.org/10.1016/S0166-5162(03)00079-X

595 Dang, D.H., Evans, R.D., Wang, W., Omanović, D., El Houssainy, A., Lenoble, V., Mullot, J.596 U., Mounier, S., Garnier, C., 2018. Uranium isotope geochemistry in modern coastal sediments: 597 Insights from Toulon Bay, France. Chemical Geology 481, 133-145. 598 https://doi.org/10.1016/j.chemgeo.2018.01.032

599 Dang, D.H., Schäfer, J., Brach-Papa, C., Lenoble, V., Durrieu, G., Dutruch, L., Chiffoleau, J.600 F., Gonzalez, J.-L., Blanc, G., Mullot, J.-U., Mounier, S., Garnier, C., 2015. Evidencing the 601 Impact of Coastal Contaminated Sediments on Mussels Through $\mathrm{Pb}$ Stable Isotopes 
602 Composition. Environ. Sci. Technol. $\quad 49, \quad 11438-11448$.

603 https://doi.org/10.1021/acs.est.5b01893

604 Djingova, R., Heidenreich, H., Kovacheva, P., Markert, B., 2003. On the determination of 605 platinum group elements in environmental materials by inductively coupled plasma mass 606 spectrometry and microwave digestion. Anal. Chim. Acta 489, 245-251. 607 https://doi.org/10.1016/S0003-2670(03)00716-5

608 Duffa, C., Dufois, F., Coudray, S., 2011. An operational model to simulate post-accidental 609 radionuclide transfers in Toulon marine area: preliminary development. Ocean Dyn. 61, 1811610 1821. https://doi.org/10.1007/s10236-011-0429-0

611 Durrieu de Madron, X., Guieu, C., Sempéré, R., Conan, P., Cossa, D., D’Ortenzio, F., 612 Estournel, C., Gazeau, F., Rabouille, C., Stemmann, L., Bonnet, S., Diaz, F., Koubbi, P., 613 Radakovitch, O., Babin, M., Baklouti, M., Bancon-Montigny, C., Belviso, S., Bensoussan, N., 614 Bonsang, B., Bouloubassi, I., Brunet, C., Cadiou, J.-F., Carlotti, F., Chami, M., Charmasson, 615 S., Charrière, B., Dachs, J., Doxaran, D., Dutay, J.-C., Elbaz-Poulichet, F., Eléaume, M., 616 Eyrolles, F., Fernandez, C., Fowler, S., Francour, P., Gaertner, J.C., Galzin, R., Gasparini, S., 617 Ghiglione, J.-F., Gonzalez, J.-L., Goyet, C., Guidi, L., Guizien, K., Heimbürger, L.-E., Jacquet, 618 S.H.M., Jeffrey, W.H., Joux, F., Le Hir, P., Leblanc, K., Lefèvre, D., Lejeusne, C., Lemé, R., 619 Loÿe-Pilot, M.-D., Mallet, M., Méjanelle, L., Mélin, F., Mellon, C., Mérigot, B., Merle, P.-L., 620 Migon, C., Miller, W.L., Mortier, L., Mostajir, B., Mousseau, L., Moutin, T., Para, J., Pérez, 621 T., Petrenko, A., Poggiale, J.-C., Prieur, L., Pujo-Pay, M., Pulido-Villena, Raimbault, P., Rees, 622 A.P., Ridame, C., Rontani, J.-F., Ruiz Pino, D., Sicre, M.A., Taillandier, V., Tamburini, C., 623 Tanaka, T., Taupier-Letage, I., Tedetti, M., Testor, P., Thébault, H., Thouvenin, B., Touratier, 624 F., Tronczynski, J., Ulses, C., Van Wambeke, F., Vantrepotte, V., Vaz, S., Verney, R., 2011. 625 Marine ecosystems' responses to climatic and anthropogenic forcings in the Mediterranean. 
627 Erk, M., Ivanković, D., Župan, I., Čulin, J., Dragun, Z., Puljas, S., Peharda, M., 2018. Changes

628 in the tissue concentrations of trace elements during the reproductive cycle of Noah's Ark shells

629 (Arca noae Linnaeus, 1758). Marine Pollution Bulletin 133, 357-366.

630 https://doi.org/10.1016/j.marpolbul.2018.05.054

631 Essumang, D.K., 2008. Bioaccumulation of platinum group metals in dolphins, Stenella sp.,

632 caught off Ghana. African Journal of Aquatic Science 33, 255-259.

633 https://doi.org/10.2989/AJAS.2008.33.3.8.620

634 Finkelman, R.B., Aruscavage, P.J., 1981. Concentration of some platinum-group metals in coal.

635 Int. J. Coal Geol. 1, 95-99. https://doi.org/10.1016/0166-5162(81)90006-9

636 Folens, K., Van Acker, T., Bolea-Fernandez, E., Cornelis, G., Vanhaecke, F., Du Laing, G.,

637 Rauch, S., 2018. Identification of platinum nanoparticles in road dust leachate by single particle 638 inductively coupled plasma-mass spectrometry. Sci. Total Environ. 615, 849-856. 639 https://doi.org/10.1016/j.scitotenv.2017.09.285

640 Fowler, S.W., Oregioni, B., 1976. Trace metals in mussels from the N.W. Mediterranean. Mar.

641 Pollut. Bull. 7, 26-29. https://doi.org/10.1016/0025-326X(76)90306-4

642 Fritsche, J., Meisel, T., 2004. Determination of anthropogenic input of Ru, Rh, Pd, Re, Os, Ir 643 and Pt in soils along Austrian motorways by isotope dilution ICP-MS. Science of The Total 644 Environment 325, 145-154. https://doi.org/10.1016/j.scitotenv.2003.11.019

645 Godlewska-Żyłkiewicz, B., 2004. Preconcentration and Separation Procedures for the 646 Spectrochemical Determination of Platinum and Palladium. Microchim. Acta 147, 189-210. https://doi.org/10.1007/s00604-004-0234-2 
648 Goldberg, E.D., Hodge, V., Kay, P., Stallard, M., Koide, M., 1986. Some comparative marine

649 chemistries of platinum and iridium. Appl. Geochem. 1, 227-232.

650 https://doi.org/10.1016/0883-2927(86)90006-5

651 Ho, H.H., Swennen, R., Cappuyns, V., Vassilieva, E., Van Tran, T., 2012. Necessity of

652 normalization to aluminum to assess the contamination by heavy metals and arsenic in

653 sediments near Haiphong Harbor, Vietnam. J. Asian Earth Sci. 56, 229-239.

654 https://doi.org/10.1016/j.jseaes.2012.05.015

655 Johnson Matthey, 2017. http://www.platinum.matthey.com/services/market-research. Johnson

656 Matthey PLC (last accessed in 2018).

657 Koide, M., Goldberg, E.D., Niemeyer, S., Gerlach, D., Hodge, V., Bertine, K.K., Padova, A.,

658 1991. Osmium in marine sediments. Geochim. Cosmochim. Acta 55, 1641-1648.

659 https://doi.org/10.1016/0016-7037(91)90135-R

660 Lee, C.-T.A., Wasserburg, G.J., Kyte, F.T., 2003. Platinum-group elements (PGE) and rhenium

661 in marine sediments across the Cretaceous-Tertiary boundary: constraints on Re-PGE transport

662 in the marine environment. Geochim. Cosmochim. Acta 67, 655-670.

663 https://doi.org/10.1016/S0016-7037(02)01135-3

664 Lekhi, P., Cassis, D., Pearce, C.M., Ebell, N., Maldonado, M.T., Orians, K.J., 2008. Role of 665 dissolved and particulate cadmium in the accumulation of cadmium in cultured oysters 666 (Crassostrea gigas). Sci. Total Environ. 309-325. 667 https://doi.org/10.1016/j.scitotenv.2007.12.004

668 Li, Y.-H., Schoonmaker, J.E., 2003. Chemical Composition and Mineralogy of Marine

669 Sediments. Treatise Geochem. 7, 407. https://doi.org/10.1016/B0-08-043751-6/07088-2 
670 Loring, D.H., Rantala, R.T.T., 1992. Manual for the geochemical analyses of marine sediments

671 and suspended particulate matter. Earth Sci. Rev. 32, 235-283. https://doi.org/10.1016/0012-

$672 \quad 8252(92) 90001-\mathrm{A}$

673 Luoma, S.N., Rainbow, P.S., 2008. Metal contamination in aquatic environments: Science and 674 lateral management. Cambridge university press.

675 Martín, J., Sanchez-Cabeza, J.A., Eriksson, M., Levy, I., Miquel, J.C., 2009. Recent 676 accumulation of trace metals in sediments at the DYFAMED site (Northwestern Mediterranean 677 Sea). Mar. Pollut. Bull., Environmental Records of Anthropogenic Impacts on Coastal 678 Ecosystems 59, 146-153. https://doi.org/10.1016/j.marpolbul.2009.03.013

679 McGranahan, G., Balk, D., Anderson, B., 2007. The rising tide: assessing the risks of climate 680 change and human settlements in low elevation coastal zones. Environ. Urban. 19, 17-37. 681 https://doi.org/10.1177/0956247807076960

682 Moldovan, M., Palacios, M.A., Gómez, M.M., Morrison, G., Rauch, S., McLeod, C., Ma, R., 683 Caroli, S., Alimonti, A., Petrucci, F., Bocca, B., Schramel, P., Zischka, M., Pettersson, C., 684 Wass, U., Luna, M., Saenz, J.C., Santamaría, J., 2002. Environmental risk of particulate and 685 soluble platinum group elements released from gasoline and diesel engine catalytic converters. 686 Sci. Total Environ. 296, 199-208. https://doi.org/10.1016/S0048-9697(02)00087-6

687 Neira, P., Cobelo-García, A., Besada, V., Santos-Echeandía, J., Bellas, J., 2015. Evidence of 688 increased anthropogenic emissions of platinum: Time-series analysis of mussels (1991-2011) 689 of an urban beach. Sci. Total Environ. 514C, 366-370. 690 https://doi.org/10.1016/j.scitotenv.2015.02.016

691 Obata, H., Yoshida, T., Ogawa, H., 2006. Determination of picomolar levels of platinum in 692 estuarine waters: A comparison of cathodic stripping voltammetry and isotope dilution- 
693 inductively coupled plasma mass spectrometry. Anal. Chim. Acta 580, 32-38.

694 https://doi.org/10.1016/j.aca.2006.07.044

695 Oursel, B., Garnier, C., Durrieu, G., Mounier, S., Omanović, D., Lucas, Y., 2013. Dynamics 696 and fates of trace metals chronically input in a Mediterranean coastal zone impacted by a large 697 urban area. Mar. Pollut. Bull. 69, 137-149. https://doi.org/10.1016/j.marpolbul.2013.01.023

698 Peavy, C.C., 1958. The Importance of Platinum in Petroleum Refining. Johns. Matthey 699 Technol. Rev., Platinum Metals Review 48, 5.

700 Pougnet, F., Schäfer, J., Dutruch, L., Garnier, C., Tessier, E., Dang, H., Lanceleur, L., Mullot, 701 J. ulrich, Lenoble, V., Blanc, G., 2014. Sources and historical record of tin and butyl-tin species 702 in a Mediterranean bay (Toulon Bay, France). Environ. Sci. Pollut. Res. Int. 21, 6640-6651. 703 https://doi.org/10.1007/s11356-014-2576-6

704 Pyrzynska, K., 2015. Application of Solid Sorbents for Enrichment and Separation of Platinum 705 Metal Ions, in: Zereini, F., Wiseman, C.L.S. (Eds.), Platinum Metals in the Environment, 706 Environmental Science and Engineering. Springer Berlin Heidelberg, pp. 67-78. 707 https://doi.org/10.1007/978-3-662-44559-4_5

708 Rauch, S., Hemond, H.F., Barbante, C., Owari, M., Morrison, G.M., Peucker-Ehrenbrink, B., 709 Wass, U., 2005. Importance of Automobile Exhaust Catalyst Emissions for the Deposition of 710 Platinum, Palladium, and Rhodium in the Northern Hemisphere. Environ. Sci. Technol. 39, 711 8156-8162. https://doi.org/10.1021/es050784m

712 Rauch, S., Hemond, H.F., Peucker-Ehrenbrink, B., 2004. Recent Changes in Platinum Group 713 Element Concentrations and Osmium Isotopic Composition in Sediments from an Urban Lake.

714 Environ. Sci. Technol. 38, 396-402. https://doi.org/10.1021/es0347686 
715 Rauch, S., Lu, M., Morrison, G.M., 2001. Heterogeneity of Platinum Group Metals in Airborne

716 Particles. Environ. Sci. Technol. 35, 595-599. https://doi.org/10.1021/es000048c

717 Rauch, S., Morrison, G.M., 2008. Environmental Relevance of the Platinum-Group Elements.

718 Elements 4, 259-263. https://doi.org/10.2113/GSELEMENTS.4.4.259

719 Rauch, S., Peucker-Ehrenbrink, B., 2015. Sources of Platinum Group Elements in the

720 Environment, in: Platinum Metals in the Environment, Environmental Science and

721 Engineering. Springer, Berlin, Heidelberg, pp. 3-17. https://doi.org/10.1007/978-3-662-44559-

Rauch, S., Peucker-Ehrenbrink, B., Molina, L.T., Molina, M.J., Ramos, R., Hemond, H.F.,

724 2006. Platinum Group Elements in Airborne Particles in Mexico City. Environ. Sci. Technol. 40, 7554-7560. https://doi.org/10.1021/es061470h

Regoli, F., Orlando, E., 1994. Seasonal variation of trace metal concentrations in the digestive gland of the Mediterranean mussel Mytilus galloprovincialis: Comparison between a polluted and a non-polluted site. Arch. Environ. Contam. Toxicol. 27, 36-43. https://doi.org/10.1007/BF00203885

Rudnick, R.L., Gao, S., 2003. Composition of the Continental Crust, in: Treatise on 731 Geochemistry. Elsevier, pp. 1-64.

732 Ruggieri, N., Castellano, M., Capello, M., Maggi, S., Povero, P., 2011. Seasonal and spatial 733 variability of water quality parameters in the Port of Genoa, Italy, from 2000 to 2007. Mar. 734 Pollut. Bull. 62, 340-349. https://doi.org/10.1016/j.marpolbul.2010.10.006

735 Sageman, B.B., Lyons, T.W., 2003. 7.06 - Geochemistry of Fine-grained Sediments and

736 Sedimentary Rocks, in: Holland, H.D., Turekian, K.K. (Eds.), Treatise on Geochemistry.

737 Pergamon, Oxford, pp. 115-158. https://doi.org/10.1016/B0-08-043751-6/07157-7 
738 Schäfer, J., Eckhardt, J.-D., Berner, Z.A., Stüben, D., 1999. Time-Dependent Increase of

739 Traffic-Emitted Platinum-Group Elements (PGE) in Different Environmental Compartments.

740 Environ. Sci. Technol. 33, 3166-3170. https://doi.org/10.1021/es990033i

741 Schäfer, J., Puchelt, H., 1998. Platinum-Group-Metals (PGM) emitted from automobile

742 catalytic converters and their distribution in roadside soils. J. Geochem. Explor. 64, 307-314.

743 https://doi.org/10.1016/S0375-6742(98)00040-5

744 Sen, I.S., Peucker-Ehrenbrink, B., 2012. Anthropogenic disturbance of element cycles at the

745 Earth's surface. Environ. Sci. Technol. 46, 8601-8609. https://doi.org/10.1021/es301261x

746 Small, C., Nicholls, R.J., 2003. A global analysis of human settlement in coastal zones. J. Coast.

747 Res. 19, 584-599.

748 Soyol-Erdene, T.-O., Huh, Y., Hong, S., Hur, S.D., 2011. A 50-year record of platinum, iridium,

749 and rhodium in antarctic snow: Volcanic and anthropogenic sources. Environ. Sci. Technol. 45, 750 5929-5935. https://doi.org/10.1021/es2005732

751 Strady, E., Schäfer, J., Baudrimont, M., Blanc, G., 2011. Tracing cadmium contamination

752 kinetics and pathways in oysters (Crassostrea gigas) by multiple stable $\mathrm{Cd}$ isotope spike

753 experiments. Ecotoxicol. Environ. $\quad$ Saf. $\quad$ 74,

754 https://doi.org/10.1016/j.ecoenv.2010.10.020

755 Tessier, E., Garnier, C., Mullot, J.-U., Lenoble, V., Arnaud, M., Raynaud, M., Mounier, S., 756 2011. Study of the spatial and historical distribution of sediment inorganic contamination in the

757 Toulon bay (France). Mar. Pollut. Bull. 62, 2075-2086.

758 https://doi.org/10.1016/j.marpolbul.2011.07.022 
759 Tuit, C.B., Ravizza, G.E., Bothner, M.H., 2000. Anthropogenic Platinum and Palladium in the

760 Sediments of Boston Harbor. Environ. Sci. Technol. 34, 927-932.

761 https://doi.org/10.1021/es990666x

762 UNEP, 2017. Report of the $20^{\text {th }}$ Ordinary Meeting of the Contracting Parties to the Convention

763 for the Protection of the Marine Environment and the Coastal Region of the Mediterranean and 764 its Protocols. UNEP, Albania, 17-20 December 2017, 748pp.

765 Vyas, N., Turner, A., Sewell, G., 2014. Platinum-based anticancer drugs in waste waters of a

766 major UK hospital and predicted concentrations in recipient surface waters. Sci. Total Environ.

767 493, 324-329. https://doi.org/10.1016/j.scitotenv.2014.05.127

768 Widdows, J., 1978. Combined Effects of Body Size, Food Concentration and Season on the

769 Physiology of Mytilus edulis. J. Mar. Biol. Assoc. 58, 109-124.

770 https://doi.org/10.1017/S0025315400024449

771 Zimmermann, S., Sures, B., 2018. Lessons learned from studies with the freshwater mussel

772 Dreissena polymorpha exposed to platinum, palladium and rhodium. Sci. Total Environ. 615,

773 1396-1405. https://doi.org/10.1016/j.scitotenv.2017.09.204

774 Zorita, I., Apraiz, I., Ortiz-Zarragoitia, M., Orbea, A., Cancio, I., Soto, M., Marigómez, I., 775 Cajaraville, M.P., 2007. Assessment of biological effects of environmental pollution along the

776 NW Mediterranean Sea using mussels as sentinel organisms. Environ. Pollut. 148, 236-250.

777 https://doi.org/10.1016/j.envpol.2006.10.022 



Fig. 1: Sampling sites along the northwestern Mediterranean coast. From east to west BM: Banyuls-sur-Mer, ST: Sète, SMM: Saintes-Maries-de-la-Mer, FM: Faraman, TB: Toulon Bay with the two sampling sites TB1 and TB2 (zoom on the right panel; SB: Small Bay, LB: Large Bay), BF: Bonifacio, and GH: Genoa Harbor, Italy. Source: geoportail.gouv.fr 


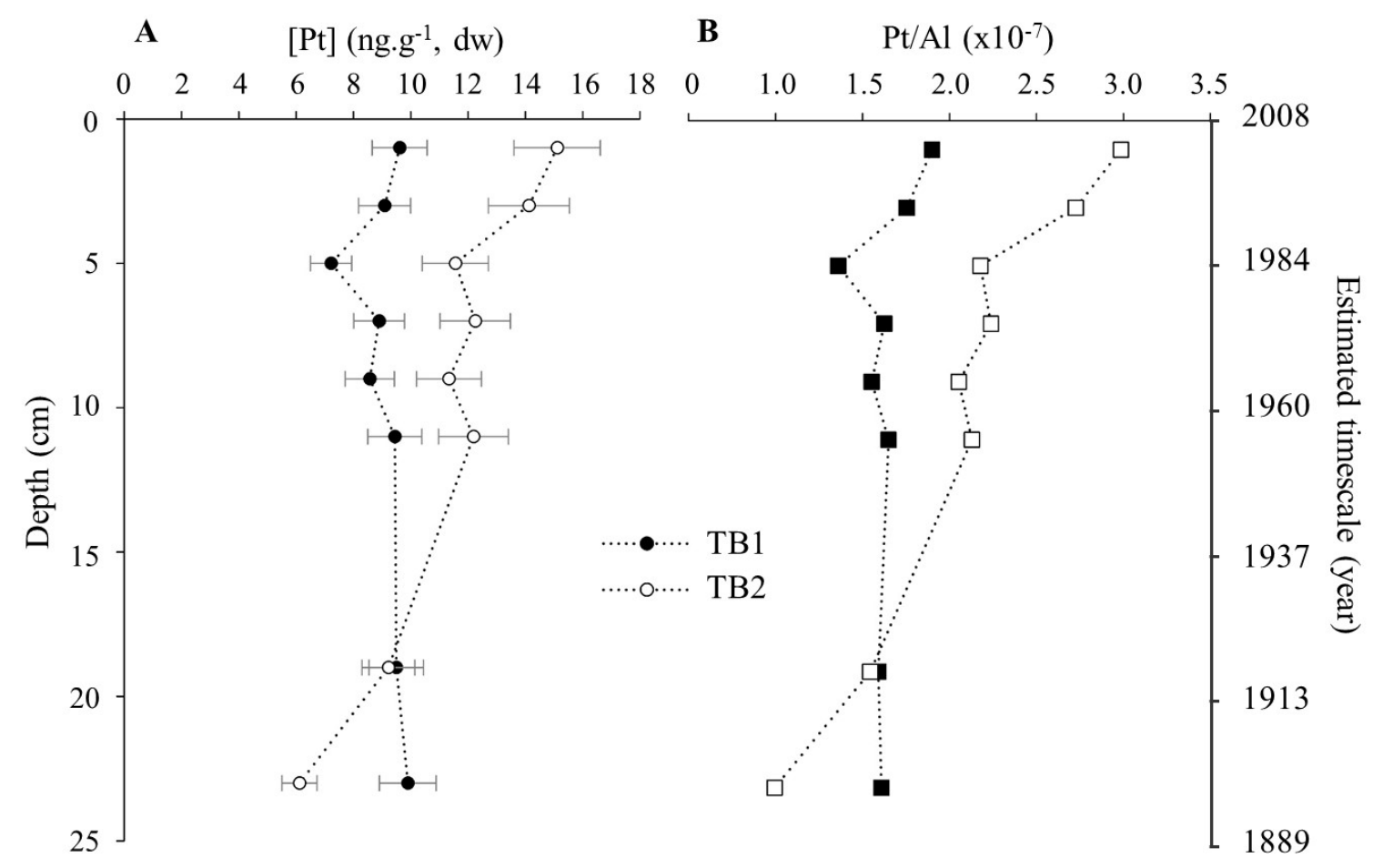

Fig. 2: Depth profiles of Pt concentrations (A) and Al-normalized Pt concentrations (B) in sediment cores from the Toulon Bay. Sediment cores were collected at site TB1 (filled symbols) and TB2 (empty symbols). A: Platinum concentrations (ng. $\mathrm{g}^{-1}$, dw: dry weight, circles), B: Aluminum-corrected Pt concentrations (x 10 $0^{-7}$, squares). Aluminum concentrations are from Tessier et al. (2011). Error bars correspond to analytical uncertainty (RSD\%). 


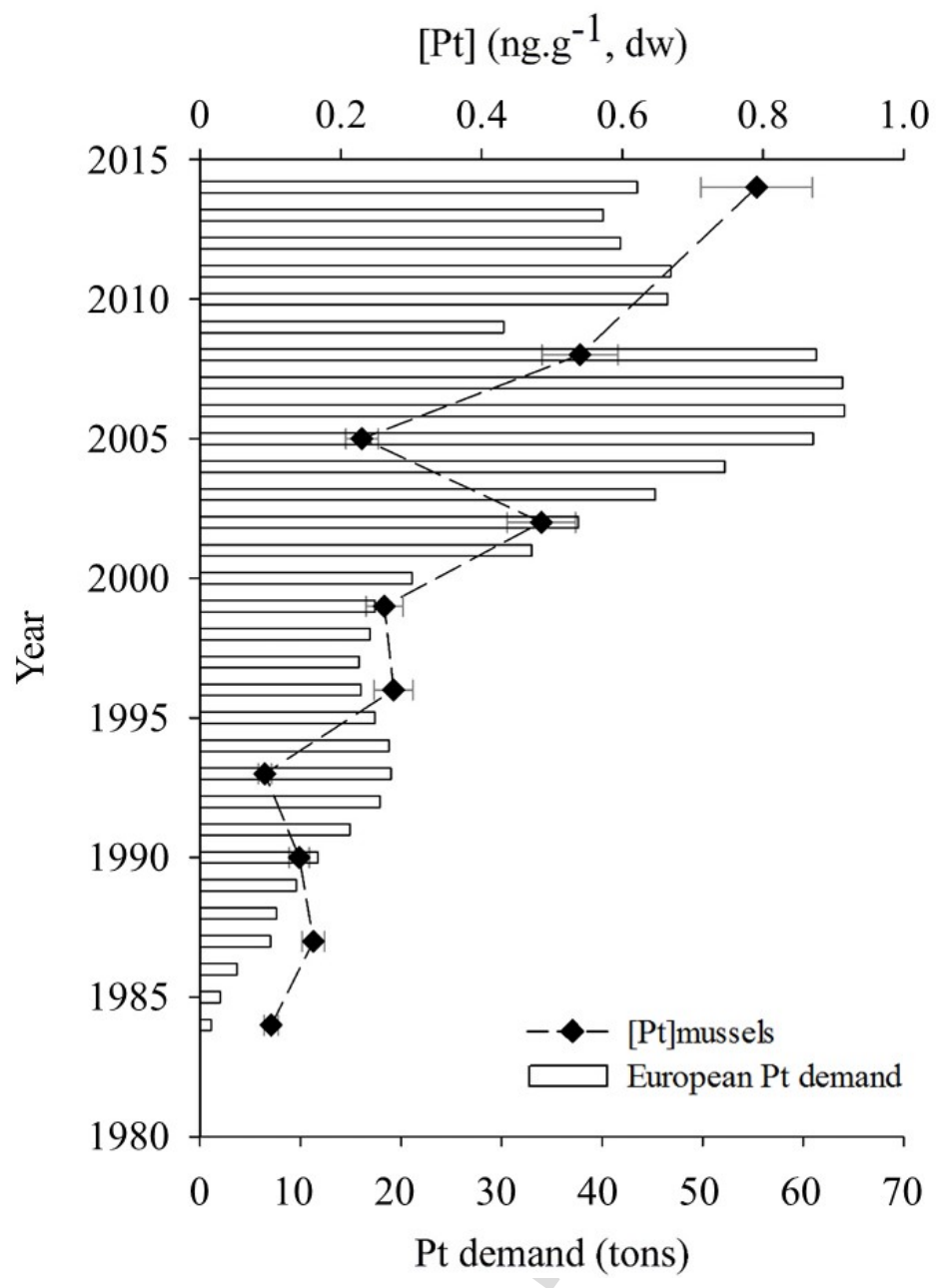

Fig. 3: Platinum concentrations in farmed mussels from the Toulon Bay (ng.g ${ }^{-1}$, dw; sampling site TB2) and European Pt gross demand (metric tons, after Johnson Matthey, 2017) for car catalytic converters during the 1984-2014 period. Error bars correspond to analytical uncertainty (RSD\%). 
BM: Banyuls-sur-Mer; ST: Sète; SMM: Saintes-Maries-de-la-Mer; FM: Faraman;

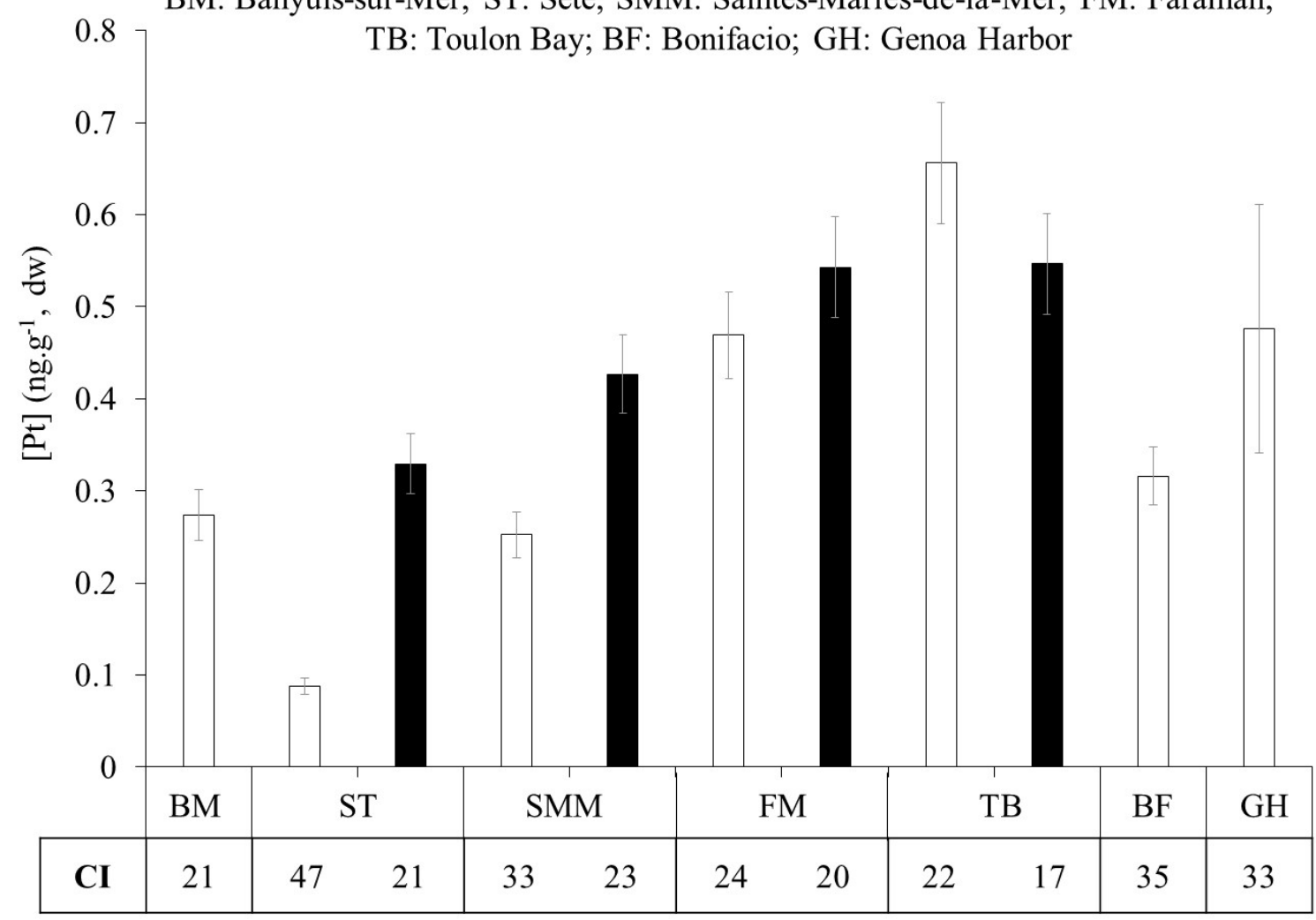

Sampling sites and Condition Index

Fig. 4: Platinum concentrations (ng. $\mathrm{g}^{-1}$, dry weight: $\mathrm{dw}$ ) in wild mussels sampled along the northwestern Mediterranean coast. Winter, Spring and Summer / Fall mussels were analyzed for the same sampling sites when possible. Black bars correspond to sample collection during Winter, whereas white bars correspond to sample collection during reproductive season (Spring and Summer / Fall); CI: average Condition Index of the mussel pools for the French coastline $(\mathrm{n} \sim 240)$ and of the 10 individuals from the Genoa Harbor. Error bars correspond to analytical uncertainty (RSD\%). 